\title{
PEMBENTUKAN VARIABEL KUNCI KEBERHASILAN AKADEMIK MAHASISWA JURUSAN TADRIS ILMU PENGETAHUAN SOSIAL
}

\author{
Yeti Nurizzati, Suniti \\ Institut Agama Islam Negeri (IAIN) Syekh Nurjati Cirebon \\ yeti@syekhnurjati.ac.id, suniti@syekhnurjati.ac.id
}

\begin{abstract}
ABSTRAK
Jurusan Tadris Ilmu Pengetahuan Sosial adalah salah satu jurusan di Fakultas Ilmu Tarbiyah dan Keguruan Institut Agama Islam Negeri Syekh Nurjati Cirebon. Jurusan tersebut telah mengupayakan agar menghasilkan lulusan tepat waktu dan IPK minimal 3. Hal ini terlihat dari hampir tidak adanya mahasiswa dropp out, sedikitnya mahasiswa yang masih aktif kuliah di lebih dari semester 8 , dan meningkatnya jumlah mahasiswa yang sudah lulus pada semester 8 . Oleh karena itulah tujuan penelitian ini dilakukan yaitu ingin mengungkap variabel apa saja yang menjadi kunci keberhasilan akademik mahasiswa di Jurusan Tadris IPS. Sampel dipilih dari mahasiswa yang berhasil secara akademik tahun angkatan 2013 dan 2014, berjumlah 51 orang sesuai dengan jumlah respon jawaban angket google form. Data mentah ini kemudian diolah menggunakan statistika deskriptif berupa tabel dan grafik, analisis prosentase, dan analisis faktor. Ada 22 variabel dari 35 variabel yang menjadi faktor keberhasilan akademik mahasiswa, dengan perolehan respon jawaban sebesar 75,56\%. Melalui analisis faktor, terbentuklah 5 kelompok yang menjadi kunci keberhasilan akademik mahasiswa yaitu kemampuan dan kebiasaan mahasiswa dalam belajar, kebijakan penilaian, dan lingkungan kampus; sikap mahasiswa dan dosen; dukungan keluarga; kemampuan mahasiswa mengimplementasikan hasil belajar, dan kesesuaian kurikulum; serta motivasi belajar.
\end{abstract}

Kata Kunci: Variabel kunci, Keberhasilan akademik, Analisis faktor

\begin{abstract}
Department of Social Sciences is one of the majors in the Faculty of Tarbiyah and Teacher Training at the Institute of Islamic Studies in the State of Sheikh Nurjati Cirebon. The Department has endeavored to produce graduates on time and a minimum GPA of 3. This can be seen from the almost no drop-out students, at least students who are still active studying in more than semester 8 , and the increasing number of students who have graduated in semester 8. Therefore That is the purpose of this research, which is to reveal what variables are key to the academic success of students in the Tadris Department of Social Sciences. Samples were selected from students who succeeded academically in the years 2013 and 2014, totaling 51 people according to the number of responses to the Google form questionnaire answers. This raw data is then processed using descriptive statistics in the form of tables and graphs, percentage analysis, and factor analysis. There are 22 variables out of 35 variables which are the factors of student academic success, with the acquisition of response responses of $75.56 \%$. Through factor analysis, five groups are formed which are the keys to student academic success, namely the ability and habits of students in learning, assessment policies, and the campus environment; the attitude of students and lecturers; family support; student's ability to implement learning outcomes, and curriculum compatibility; and learning motivation.
\end{abstract}

Keywords: Key variables, Academic success, Factor analysis 


\section{A. PENDAHULUAN}

Keberhasilan akademik mahasiswa dicirikan oleh prestasi akademik yang diperoleh yaitu nilai Indeks Prestasi Kumulatif (IPK) dan penyelesaian studi. Semakin tinggi IPK dan semakin tepat mahasiswa lulus maka semakin tinggi prestasinya. Secara global, faktor yang mempengaruhi hasil belajar dapat dibedakan menjadi tiga macam, yakni: (1) Faktor eksternal (faktor dari dalam diri siswa) yakni keadaan/kondisi jasmani dan rohani siswa. (2) Faktor eksternal (faktor dari luar siswa) yakni kondisi lingkungan di sekitar siswa. (3) Faktor pendekatan belajar (approach to learning) yakni jenis upaya belajar siswa yang meliputi strategi dan metode yang digunakan siswa untuk melakukan kegiatan pembelajaran. (Syah, 2017).

Ada banyak faktor yang mempengaruhi keberhasilan akademik mahasiswa, prestasi akademik mahasiswa, prestasi belajar mahasiswa, atau pun prestasi belajar peserta didik. Asal daerah, nilai rata-rata Ujian Nasional (UN), dan jurusan di Sekolah Menengah Atas (SMA) merupakan 3 faktor yang mempengaruhi keberhasilan akademik mahasiswa (Kurnia, 2011). Motivasi, faktor keluarga, lingkungan kampus, aktif organisasi (Saleh, 2014), prestasi pendidikan selanjutnya (Prapdopo dan Fariyanti, 2016), karakteristik mahasiswa, gaya hidup, kebiasaan belajar, motivasi belajar, dan status sosial ekonomi (Catur, 2018), komunikasi interpersonal dosen (Abubakar, 2015), motivasi belajar penting untuk dikembangkan karena dapat mempengaruhi prestasi akademik siswa, baik motivasi ekstrinsik maupun intrinsik (Lutfiwati, 2020) berpengaruh signifikan terhadap prestasi akademik mahasiswa.

Kemampuan awal mahasiswa, motivasi belajar, lingkungan belajar, dan fasilitas belajar (Saputro, 2015), minat, motivasi belajar, tingkat pendidikan orang tua, tingkat pendapatan orang tua, jumlah anak tanggungan orang tua (Mustamin, 2013), kebiasaan belajar, kemampuan dan usaha, keahlian intelektual, prestasi di SMU, prestasi di perguruan tinggi (Mahmudah, 2011) berpengaruh signifikan terhadap prestasi belajar mahasiswa. Faktor sikap orangtua terhadap anak, sikap guru terhadap peserta didik, dan self-regulated learning berpengaruh terhadap prestasi belajar peserta didik (Yuzarion, 2017). Apabila dilihat dari gender, maka 
pelajar perempuan memperoleh prestasi yang lebih baik berbanding pelajar lelaki dalam hampir kesemua mata pelajaran (Jelas, 2005). Kecerdasan emosional merupakan salah satu faktor penting yang seharusnya dimiliki oleh siswa yang memiliki kebutuhan untuk meraih prestasi belajar yang lebih baik di sekolah serta menyiapkan mereka menghadapi dunia nyata (Thaib, 2003).

Berbeda dengan penelitian sebelumnya yang hanya menguji beberapa faktor yang mempengaruhi keberhasilan atau prestasi akademik, maka penelitian ini berusaha mengeksplore faktor-faktor apa saja yang akan mempengaruhi dan membentuk keberhasilan akademik mahasiswa dimana faktor tersebut mencakup faktor internal dan eksternal. Dari sekian banyak faktor ini kemudian dikelompokkan kembali menjadi faktor kunci dalam keberhasilan akademik mahasiswa. Dalam hal ini, mahasiswa yang diteliti adalah mahasiswa Jurusan Tadris Ilmu Pengetahuan Sosial (IPS) Institut Agama Islam Negeri (IAIN) Syekh Nurjati Cirebon.

Hasil wawancara dengan beberapa mahasiswa dari studi awal di lapangan diperoleh bahwa ada mahasiswa yang tidak mempunyai catatan kuliah sendiri dan hanya mengandalkan fotokopi catatan temannya, tidak mempelajari bahan kuliah sebelum diajarkan dosen, tidak mempelajari kembali materi kuliah yang telah diberikan dosen setelahnya, belajar bila menjelang ujian saja baik ujian tengah semester maupun ahir semester atau bila ada tugas dari dosen yang memerlukan pemahaman. Oleh karena itu, keberhasilan akademik mahasiswa menjadi kurang maksimal dengan IP rendah dan lama menyelesaikan studinya.

Di sisi lain, Jurusan Tadris IPS berusaha mendorong mahasiswanya agar lulus tepat waktu. Mulai awal semester 7, mahasiswa sudah mulai dibimbing untuk mengajukan proposal penelitian sehingga awal semester 8, mahasiswa dapat melaksanakan penelitian dan lulus 4 tahun. Bahkan, beberapa mahasiswa sudah dapat melaksanakan penelitian sambil kuliah dan menyelesaikan studinya kurang dari 8 semester dengan IPK minimal 3. Oleh karena itulah penelitian ini dilakukan yakni agar dapat mengungkap variabel apa yang menjadi kunci keberhasilan akademik mahasiswa. Adapun permasalahan yang akan dibahas adalah (1) karakteristik mahasiswa Jurusan Tadris IPS yang berhasil akademiknya (2) 
variabel-variabel yang mempengaruhi keberhasilan akademik mahasiswa Jurusan Tadris IPS (3) variabel yang menjadi kunci keberhasilan akademik mahasiswa Jurusan Tadris IPS. Sehingga manfaat penelitian ini adalah menjadi pendorong bagi mahasiwa jurusan Tadris IPS untuk mencapai keberhasilan akademiknya, memberikan masukan bagaimana caranya agar dosen mampu berkontribusi dalam mencetak mahasiswa yang berhasil akademik, serta menjadi inspirasi bagi manajemen jurusan Tadris IPS untuk meningkatkan mutu layanan kepada mahasiswa.

\section{B. METODE PENELITIAN}

Pendekatan yang digunakan adalah kuantitatif dengan jenis expost facto, populasinya adalah seluruh mahasiswa Jurusan Tadris IPS tahun Angkatan 2013/2014 dan 2014/2015 yang lulus paling lambat bulan Agustus atau maksimal semester 8 berjumlah 113 mahasiswa terdiri dari 50 mahasiswa angkatan 2013 dan 63 mahasiswa angkatan 2014, sedangkan sampelnya adalah seluruh populasi yang mengisi angket sesuai waktu yang telah ditentukan yakni berjumlah 51 orang $(45,13 \%)$ melalui teknik simple random sampling. Teknik pengumpulan data yang dipergunakan yaitu observasi, studi dokumentasi, dan penyebaran angket; dimana observasi dilakukan dengan cara mengamati keseharian mahasiswa di dalam lingkungan kampus, baik di dalam maupun luar kelas secara partisipatif maupun non partisipatif; dokumen-dokumen yang dimiliki oleh Jurusan Tadris IPS, buku, karya ilmiah, jurnal ilmiah, dan tulisan-tulisan lainnya yang terkait dengan keberhasilan akademik mahasiswa, menjadi sumber dokumentasi sekunder.

Instrumen utama menggunakan angket berisi daftar pernyataan yang merupakan indikator dari faktor-faktor keberhasilan akademik mahasiswa dengan total pernyataan angket berjumlah 35 item terdiri dari 18 pernyataan positif dan 17 pernyataan negative melalui pilihan jawaban angket menggunakan skala likert yaitu sangat setuju (SS), setuju (S), tidak setuju (TS), dan sangat tidak setuju (STS) dan dibuat di google form agar memudahkan responden mengisi. Sebelum dilakukan analisis data, terlebih dahulu dilakukan uji validitas dan reliabilitas instrument yang diuji dengan menggunakan uji pakar melalui Focus Group Discussion (FGD) sehingga diperoleh saran perbaikan item-item angket baik dari segi jumlah item 
maupun isi pernyataan item dan jenisnya. Teknik analisis data menggunakan statistik deskriptif untuk mendeskripsikan atau memberikan gambaran terhadap objek yang diteliti melalui penyajian tabel, grafik, atau diagram; skala prosentase untuk menganalisis variabel-variabel yang menjadi faktor keberhasilan akademik mahasiswa dinyatakan dalam persen; serta analisis faktor untuk mengidentifikasi, mengelompokkan, dan meringkas atau mereduksi variabel-variabel yang saling bebas (independent) menjadi lebih sedikit variabel.

\section{HASIL DAN PEMBAHASAN}

1. Karakteristik Mahasiswa Jurusan Tadris IPS Yang Berhasil Akademiknya

Setiap mahasiswa, pastilah ingin berhasil selama belajar di perguruan tinggi. Secara akademik, keberhasilan ini bisa dilihat dari lulus tepat waktu dengan IPK tinggi. Tentunya, keberhasilan ini mereka gunakan sebagai modal bersaing dalam dunia usaha. Jurusan Tadris IPS, adalah salah satu jurusan di Fakultas Ilmu Tarbiyah dan Keguruan IAIN Syekh Nurjati Cirebon, berupaya agar dapat memenuhi harapan mahasiswa ini. Pada penelitian ini, hanya melihat dua angkatan yaitu angkatan 2013 dan 2014 dengan jumlah mahasiswa yang berhasil di bidang akademik angkatan 2013 sebesar 50 orang, dan angkatan 2014 sebanyak 63 orang. Jadi, ada peningkatan jumlah mahasiswa yang berhasil secara akademik di Jurusan Tadris IPS. Guna mendapatkan data apa saja faktor yang menjadi keberhasilan akademik mahasiswa, maka disusunlah angket yang terdiri dari 18 item pernyataan positif dan 17 item pernyataan negatif sehingga total 35 item atau 35 variabel. Angket kemudian disebar kepada responden melalui google form dengan alamat https://forms.gle/SPGUEHrn6mxqZgxP7. Respon angket yang masuk berasal dari 51 mahasiswa, kemudian jawaban diberikan skor dan diolah menggunakan Statistical Package for Social System (SPSS) versi 21. Karakteristik responden dilihat dari tahun masuk dimana angkatan tahun 2013 sebanyak 11 orang, dan 2014 sebanyak 40 orang. Dilihat dari jenis kelamin, terdiri dari 42 perempuan dan 9 laki-laki. Dilihat dari lama studi, maka mahasiswa yang berhasil akademik adalah mahasiswa yang lulus paling lambat 4 tahun. Dari responden yang ada, masa studi paling cepat adalah 3,5 tahun dan rata-ratanya 3,71 tahun. Sedangkan karakteristik mahasiswa yang 
berhasil akademiknya adalah mahasiswa yang memiliki nilai IPK minimal 3. IPK terendah responden adalah 3,25; terbesar 3,65 dan rata-rata 3,42.

2. Variabel-Variabel Yang Mempengaruhi Keberhasilan Akademik Mahasiswa Jurusan Tadris IPS

Melalui uji Kaiser-Meyer-Olkin (KMO) diperoleh nilai 0,711 dan 22 variabel memiliki nilai Measures of Sampling Adequacy (MSA) > 0,5, sehingga dapat dikatakan bahwa ada 22 variabel yang mempengaruhi keberhasilan akademik. Rata-rata skor 22 variabel diperoleh sebesar 75,56\% dalam kategori sangat baik. Dua puluh dua variabel yang menjadi faktor keberhasilan akademik tersebut yaitu lebih dari setengahnya (53\%) tidak setuju bahwa belajar itu cukup diperoleh saat pembelajaran di kelas, lebih dari setengahnya (55\%) setuju bahwa mahasiswa tidak mau ketinggalan materi kuliah, dan sebagian besar (76\%) setuju bahwa suasana kelas yang ribut akan menghilangkan konsentrasi belajar. Sebagian besar (74\%) setuju bahwa penggunaan modul lebih memudahkan mahasiswa memahami materi kuliah, sebagian besar (74\%) setuju bahwa modul dapat digunakan sebagai sumber belajar untuk menyelesaikan tugas kuliah, sebagian besar (72\%) mahasiswa mempelajari modul di luar kelas, dan hanya sedikit sekali (6\%) mahasiswa yang membaca modul saat pembelajaran di kelas. Sebagian besar (61\%) mahasiswa mengaitkan teori di kelas dengan kehidupan sehari-hari, sebagian besar $(86 \%)$ mahasiswa mampu menjelaskan kembali materi kuliah kepada teman, hampir setengahnya (49\%) mahasiswa tidak setuju bahwa mereka belum mampu memecahkan masalah sosial di lingkungan kampus, sebagian besar (67\%) mahasiswa tidak setuju bahwa mereka tidak berani mengemukakan pendapat di dalam kelas, sebagian besar $(63 \%)$ setuju bahwa mahasiswa memikirkan terlebih dahulu baik buruknya sebelum bertindak, sebagian besar (61\%) setuju bahwa untuk mendapatkan hasil maksimal maka mahasiswa belajar secara rutin, dan sedikit sekali (2\%) mahasiswa yang terbiasa belajar kalau mau ada ujian.

Lebih dari setengahnya (55\%) mahasiswa yang menyatakan bahwa dosendosen Tadris IPS memiliki kompetensi ilmu sesuai dengan bidangnya, sedikit sekali (2\%) mahasiswa yang sangat setuju terhadap pernyataan bahwa pendapat 
mahasiswa itu salah sedangkan dosenlah yang benar, sebagian besar (61\%) mahasiswa tidak setuju bahwa penilaian mata kuliah di Jurusan Tadris IPS hanya pada ranah kognitif, sebagian besar (70\%) mahasiwa setuju bahwa tidak boleh bekerjasama dengan teman saat ujian, sebagian besar (84\%) mahasiswa setuju bahwa kurikulum Jurusan Tadris IPS mengacu pada kurikulum Standar Nasionak Perguruan Tinggi (SNPT). Lebih dari setengahnya (55\%) mahasiswa menyatakan sangat setuju bahwa orang tua menginginkan pendidikan anaknya lebih tinggi darinya, sebagian besar (61\%) mahasiswa setuju bahwa mereka kuliah sambil bekerja untuk membantu ekonomi orang tua, dan sedikit sekali (4\%) mahasiswa yang malas belajar karena ada masalah dalam keluarga.

Dari hasil ini, dapat dijelaskan bahwa keberhasilan akademik mahasiswa disebabkan oleh suasana kelas yang mendukung untuk tetap menjaga konsentrasi belajar, penggunaan modul yang lebih memudahkan mahasiswa memahami materi kuliah, juga menyelesaikan tugas kuliah. Modul ini dipelajari tidak hanya saat pembelajaran di kelas tapi juga di luar kelas. Agar mudah mengingat materi kuliah, mahasiswa mengaitkan teori di kelas dengan kehidupan sehari-hari sehingga mahasiswa mampu menjelaskan kembali materi kuliah kepada teman. Di dalam kelas, mahasiswa berani mengemukakan pendapat. Dan sebelum bertindak, mahasiswa memikirkan terlebih dahulu baik buruknya. Mahasiswa belajar secara rutin, bukan kalau mau ada ujian saja. Saat ujian, mereka tidak bekerjasama dengan teman. Selain itu, penilaian mata kuliah di Jurusan Tadris IPS tidak hanya pada ranah kognitif, dan kurikulum Jurusan Tadris IPS mengacu pada kurikulum SNPT. Masalah dalam keluarga, tidak membuatnya malas belajar. Bahkan mereka kuliah sambil bekerja untuk membantu ekonomi orang tua.

Hal ini sejalan dengan teori yang mengatakan bahwa ada dua faktor yang mempengaruhi keberhasilan akademik mahasiswa yakni faktor internal dan faktor eksternal. Faktor internal meliputi sikap terhadap belajar, motivasi belajar, kosentrasi belajar, mengolah bahan ajar, menyimpan perolehan hasil belajar, menggali hasil belajar yang tersimpan, kemampuan berprestasi atau unjuk hasil belajar, rasa percaya diri siswa, inetelegensi dan keberhasilan belajar, kebisaan 
belajar, dan cita-cita. Sedangkan faktor eksternal meliputi faktor guru/dosen sebagai pengajar, prasarana dan sarana pembelajaran, kebijakan penilaian, lingkungan sosial siswa/mahasiswa di sekolah/kampus, kurikulum sekolah, serta dukungan keluarga. (Dimyati, 2009).

3. Variabel yang menjadi kunci keberhasilan akademik mahasiswa Jurusan Tadris IPS

Analisis komponen utama digunakan untuk mengekstrak 22 variabel, sehingga diperoleh 6 kelompok yang dipilih dari nilai eigen $>1$. Variabel motivasi belajar negatif masuk kelompok 5, motivasi belajar positif kelompok 1, konsentrasi belajar kelompok 1, mengolah bahan ajar 1 dan 2 kelompok 1, menyimpan perolehan bahan ajar positif dan negatif kelompok 1, menggali hasil belajar yang tersimpan kelompok 1, unjuk hasil belajar positif kelompok 1, unjuk hasil belajar negatif kelompok 4, rasa percaya diri negatif kelompok 2, intelegensi hasil belajar kelompok 1, kebiasaan belajar positif dan negatif kelompok 1, faktor dosen positif kelompok 2, faktor dosen negatif kelompok 1, kebijakan penilaian negatif kelompok 1, lingkungan sosial kampus kelompok 1 , kurikulum kelompok 4, dukungan keluarga positif kelompok 3 dan 6, serta dukungan keluarga negatif kelompok 1.

Pemilihan anggota kelompok ini dipilih berdasarkan nilai korelasi yang paling besar diantara 6 kelompok tersebut. Namun, ada dua kelompok yang anggotanya sama yaitu kelompok 3 dan 6 dengan anggota dukungan keluarga positif, sehingga dijadikan satu kelompok. Jadi, terbentuklah 5 kelompok yang menjadi variabel kunci keberhasilan akademik. Kelompok 1 adalah kemampuan dan kebiasaan mahasiswa dalam belajar, serta tidak adanya dukungan dari faktor dosen, kebijakan penilaian, lingkungan kampus dan keluarga. Kelompok 2 adalah sikap minder mahasiswa dan dukungan dosen. Kelompok 3 adalah dukungan keluarga. Kelompok 4 adalah ketidakmampuan mahasiswa mengimplementasikan hasil belajar, dan kesesuaian kurikulum. Kelompok 5 adalah kurangnya motivasi siswa dalam belajar. Dari kelima kelompok tersebut di dalamnya sudah mencakup faktor internal dan eksternal yang mempengaruhi keberhasilan akademik mahasiswa. 
Hal ini sejalan dengan pendapat Munandar dalam Sampoerno bahwa kualitas mahasiswa dipengaruhi oleh banyak faktor, antara lain: (1) Latar belakang keluarga; dukungan orang tua, tingkat sosial ekonomi orang tua; (2) Lingkungan belajar di rumah; prasarana dan sarana yang tersedia; (3) Lingkungan kampus dan dosennya; mampu bersosialisasi; (4) Motivasi; minat untuk berprestasi, keuletan. (Sampoerno, 2002).

Kebiasaan belajar yang baik dari seorang mahasiswa dapat dipupuk melalui pengalaman sukses yang dialami diri sendiri, yang akhirnya menumbuhkan sikap positif terhadap cara belajar yang dilakukan. Bisa juga ditumbuhkan dengan melihat sikap dosen yang menjadi teladan dan panutan sehingga mahasiswa bisa meniru dan bertindak sama. Kebiasaan belajar didasarkan pada perkiraan jumlah jam belajar yang dilakukan oleh seorang mahasiswa pada setiap minggunya. Namun demikian, kualitas dan kuantitas pembelajaran adalah sama pentingnya. Mahasiswa yang berjam-jam belajar secara terus menerus akan cenderung tidak efektif dan jarang mengarah pada kesuksesan akademis. Tidur menjadi berkurang, tidur dengan kualitas kurang baik karena gelisah, yang nantinya berdampak pada kesehatan yang kurang terjaga.

Sikap dosen dalam pembelajaran di kelas hendaknya dapat menciptakan suasana belajar yang kondusif yaitu kondisi belajar yang penuh dengan kenyamanan, ketenangan, bersemangat dalam belajar, dan jauh dari rasa takut dalam belajar. Dosen dalam menyampaikan materi kuliah dilakukan dengan menyenangkan, jelas dan terarah sehinggaa mahasiswa dapat menerima pesanpesan tersebut dengan baik pula. Mahasiswa menjadi rileks dalam belajar sehingga dapat mendorong mereka berprestasi dalam belajar. Sikap ini yang dibutuhkan mahasiswa secara psikologis dalam menata dirinya untuk mencapai prestasi belajar secara maksimal.

Kebijakan penilaian dosen ikut mempengaruhi keberhasilan akademik mahasiswa. Dosen yang memberikan penilaian secara transparan dan adil akan membuat mahasiswa merasa tidak sia-sia dalam belajar. Terhadap nilai yang belum mencapai target kelulusan, maka dosen hendaknya lebih toleran dengan 
memberikan remedial atau tes perbaikan. Selain itu terhadap tugas-tugas perkuliahan yang dibebankan kepada mahasiswa, dosen tidak membedakan antara mahasiswa satu dengan mahasiswa lainnya. Dosen juga sebaiknya memberikan penilaian yang disertai komentar terhadap hasil tugas mahasiswa sehingga mahasiswa mengetahui letak kekeliruannya dan bisa memperbaikinya.

Lingkungan kampus merupakan tempat mahasiswa berinteraksi bersama civitas akademika yaitu dosen, karyawan, atau teman-temannya di dalam kampus. Kalau ada persaingan yang tidak sehat dengan teman sekelasnya maka akan mengganggu mereka belajar sehingga berakibat pada turunnya prestasi akademik yang dicapai. Baik buruknya kondisi lingkungan fisik juga akan berpengaruh terhadap prestasi belajar peserta didik dimana kondisi lingkungan yang gaduh, kotor, panas, menyebabkan belajarnya menjadi kurang efektif. Sebaliknya kondisi yang tenang dan bersih, sejuk, segar akan membantu meningkatkan konsentrasi dalam belajar. Lingkungan non fisik juga memiliki peran yang besar dalam pengaruhnya terhadap kondisi belajar terutama pengaturan lingkungan belajar, penampilan, sikap dosen, hubungan yang harmonis antara dosen dengan mahasiswa dan antara sesama mahasiswa, serta organisasi dan bahan pembelajaran secara tepat, sesuai dengan kemampuan dan perkembangan mahasiswa.

Lingkungan keluarga merupakan lingkungan pertama yang mempunyai pengaruh kuat kepada mahasiswa dibandingkan dengan lingkungan sekunder yang ikatannya agak longgar. Mahasiswa yang berada pada lingkungan keluarga yang harmonis dapat membimbing mahasiswa untuk mencapai prestasi yang optimal. Mahasiswa menjadi fokus belajar tanpa ada beban hidup yang akan mengganggu konsentrasi dalam belajar. Namun, berbeda dengan hasil penelitian Gorkaz, Banimahd \& Esmaeili (2011) yang dikutip oleh Indriana dkk (2016) bahwa dukungan keluarga tidak memiliki pengaruh yang signifikan terhadap prestasi akademik mahasiswa, sehingga hal tersebut menunnjukkan bahwa tidak ada perbedaan antara mahasiswa yang didukung keluarga maupun tidak. (TL, Widowati, \& Surjawati, 2016). 
Hubungan dosen dan mahasiswa dalam proses belajar mengajar merupakan faktor yang sangat penting dalam menciptakan suasana belajar yang menyenangkan, sehingga mahasiswa termotivasi. Motivasi belajar mahasiswa akan terlihat pada perilakunya antara lain dijabarkan bagaimana keaktifannya dalam belajar untuk mencapai prestasi, dalam menyelesaikan tugas, pemanfaatan waktu serta bagaimana bersikap untuk mengatasi hambatan dalam belajar. Dalam hal ini, ada sedikit kesadaran dari mahasiswa bahwa jika perilaku belajar dan motivasi semakin baik, maka akan menghasilkan prestasi belajar yang maksimal. (Poerwati, 2010). Mahasiswa akan mempunyai motivasi untuk mengikuti materi kuliah dengan baik apabila dosen bersikap terbuka, menunjukkan empati terhadap persoalan yang dihadapi mahasiswa. Dibutuhkan konsistensi dalam membangun suasana kelas yang nyaman, suportif dan menyenangkan untuk membantu mahasiswa yang memiliki motivasi belajar rendah. Hal ini dimaksudkan untuk mengembangkan motivasi ekstrinsik yang akan menstimulasi tumbuhnya motivasi intrinsik pada mahasiswa tersebut,

Mahasiswa yang mampu mengimplementasikan hasil belajarnya di kelas, dapat dilihat dari sikap dan kontribusinya pada masyarakat di sekitarnya. Mereka akan mampu memberikan kontribusi nyata seperti memberikan ide dan solusi tarhadap masalah yang ada. Oleh karena itu, kesesuaian kurikulum dengan kebutuhan masyarakat juga harus selaras. Apa yang dibutuhkan dunia kerja menjadi capaian lulusan program studi, sehingga alumni yang dihasilkan dapat terserap dalam dunia kerja bahkan menciptakan tenaga kerja.

\section{KESIMPULAN}

Berdasarkan uraian dari hasil dan pembahasan dapat disimpulkan hal-hal sebagai berikut: (a) Karakteristik Mahasiswa Jurusan Tadris IPS yang berhasil di bidang akademik adalah mahasiswa yang lulus maksimal 4 tahun, dan IPK minimal 3. Dari data responden sejumlah 51 orang, rata-rata lulus 3,71 tahun ( 3 tahun 8 bulan 15 hari) dan rata-rata IPK 3,42. (b) Variabel yang menjadi faktor-faktor yang mempengaruhi keberhasilan akademik mahasiswa berjumlah 22 meliputi faktor internal dan eksternal yaitu motivasi belajar (positif dan negatif), konsentrasi belajar, mengolah bahan ajar (1 dan 2), menyimpan perolehan bahan ajar (positif 
dan negatif), menggali hasil belajar yang tersimpan, unjuk hasil belajar (positif dan negatif), rasa percaya diri negatif, intelegensi dan keberhasilan belajar, kebiasaan belajar (positif dan negatif), faktor dosen (positif dan negatif), kebijakan penilaian negatif, lingkungan sosial kampus, kurikulum, dukungan keluarga (positif 1 dan 2, serta negatif). (c) Kunci keberhasilan akademik mahasiswa yang terbentuk menjadi 5 kelompok. Kelompok pertama adalah kemampuan dan kebiasaan mahasiswa dalam belajar, kebijakan penilaian, dan lingkungan kampus. Kelompok dua adalah sikap mahasiswa dan dosen. Kelompok tiga adalah dukungan keluarga. Kelompok empat adalah kemampuan mahasiswa mengimplementasikan hasil belajar, dan kesesuaian kurikulum. Kelompok lima adalah motivasi belajar.

Beberapa saran yang perlu diperhatikan oleh pihak yang terkait agar keberhasilan akademik mahasiswa dapat terus ditingkatkan, yaitu: (a) Mahasiswa agar dapat meningkatkan motivasi belajar, konsentrasi dalam belajar, menumbuhkan kebiasaan yang baik, memahami dan mengaitkan antar materi kuliah. (b) Dosen agar dapat meningkatkan kompetensinya, menerapkan kebijakan penilaian yang adil dan transparan. (c) Manajemen jurusan agar selalu mengupdate kurikulum sesuai dengan kebutuhan, dan memelihara lingkungan sosial kampus yang kondusif. (d) Orang tua agar bisa memberikan dukungan belajar terhadap anaknya secara materil maupun moril.

\section{DAFTAR PUSTAKA}

Abubakar, F. (2015). Pengaruh Komunikasi Interpersonal antara Dosen dan Mahasiswa Terhadap Motivasi Belajar dan Prestasi Akademik Mahasiswa. Jurnal Pekomnas, 18(1), 53-62.

Catur, M. M. S. P. A. R. dan D. O. (2018). Faktor-Faktor yang Memengaruhi Prestasi Akademik pada Mahasiswa Kedokteran Tahap Preklinik. JIMKI, 6(2), 109-116.

Dimyati. (2009). Belajar dan Pembelajaran. Jakarta: Rineka Cipta.

Jelas, Z. M. dkk. (2005). Prestasi Akademik Mengikut Gender. Jurnal Pendidikan 30, 93-111.

Kurnia, L. (2011). Analisis Faktor Faktor yang Mempengaruhi Keberhasilan Akademik Mahasiswa STAIN Batusangkar. Jurnal Sainstek, III(2), 97-111.

Lutfiwati, S. (2020). Motvasi Belajar dan Prestasi Akademik. Al-Idarah: Jurnal Kependidikan Islam, 10(1), 53-63. 
Mahmudah, N. A. dan A. I. S. (2011). Faktor-faktor yang Mempengaruhi Pestasi Belajar dalam Mata Kuliah Akuntansi Keuangan Menengah I (Studi Empiris pada Mahasiswa Akuntansi Perguruan Tinggi Negeri dan Perguruan Tinggi Swasta di Semarang). Jumal Akuntansi Bisnis, IX(18), 110-130.

Mustamin, S. H. dan S. S. (2013). Faktor-faktor yang Mempengaruhi Prestasi Belajar Mahasiswa Jurusan Pendiikan matematika Fakultas tarbiyah dan Keguruan UIN Alauddin Makassar. JURNAL MATEMATIKA DAN PEMBELAJARAN (MAPAN), 1(1), 151-177.

Poerwati, T. (2010). Pengaruh Perilaku Belajar dan Motivasi terhadap Prestasi Akademik Mahasiswa Akuntansi di Universitas STIKUBANK (UNISBANK) Semarang. Majalah Ilmiah Universitas Pandanaran, 8(16).

Prapdopo dan Fariyanti. (2016). Analisis Beberapa Faktor yang Mempengaruhi Prestasi Akademik Mahasiswa. Jurnal Eksis, 12(1), 3267-3273.

Saleh, M. (2014). Pengaruh Motivasi, Faktor Keluarga, Lingkungan Kampus dan Aktif Berorganisasi terhadap Prestasi Akademik. Jurnal Phenomenon, 4(2), 109-141.

Sampoerno, P. (2002). Analisis Kualitas Mahasiswa dalam Pencapaian Pendidikannya dengan Menggunakan Metode Partial Least Squares. Studi kasus: Mahasiswa Jurusan Matematika FMIPA Universitas Jakarta. IPB.

Saputro, M. A. dan D. F. (2015). Faktor-faktor yang Mempengaruhi Prestasi Belajar (Studi Korelasi Pada Mahasiswa Pendidikan Matekamtika IKIP PGRI Pontianak). Jurnal Pendidikan Informatika Dan Sains, 4(2), 233-246.

Syah, M. (2017). Psikologi Belajar (15th ed.). Depok: Rajawali Pers.

Thaib, E. N. (2003). Hubungan antara Prestasi Belajar dengan Kecerdasan Emosional. Jurnal Ilmiah DIDAKTIKA, XIII(2), 384-399.

TL, D. I., Widowati, A. I., \& Surjawati, S. (2016). Faktor-Faktor Yang Mempengaruhi Prestasi Akademik: Studi Kasus Pada Mahasiswa Program Studi Akuntansi Universitas Semarang. Jurnal Dinamika Sosial Budaya, 18(1), 39-48. https://doi.org/10.26623/jdsb.v18i1.557

Yuzarion. (2017). Faktor yang Mempengaruhi Prestasi Belajar Peserta Didik. Ilmu Pendidikan, 2(1), 107-117. 